Supporting Information belonging to the manuscript:

\title{
Cu-Catalyzed Synthesis of Symmetric Group 6 Fischer bis-Carbene Complexes
}

María P. López-Alberca, María J. Mancheño, * Israel Fernández, Mar Gómez-Gallego, and Miguel A. Sierra,*

Departamento de Química Orgánica, Facultad de Química, Universidad Complutense, 28040-Madrid (Spain)

MJM:mjmreal@quim.ucm.es, MAS: sierraor@quim.ucm.es 


\section{Table of contents}

\section{Index}

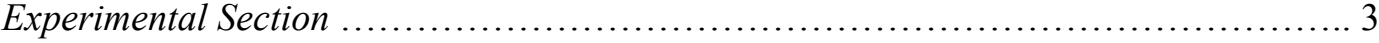

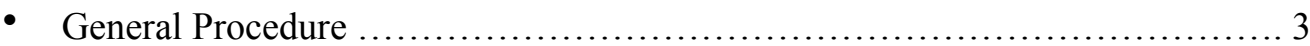

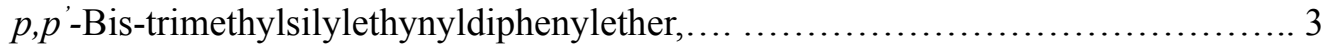

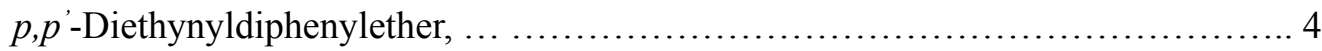

- General Method for the synthesis of carbene complexes $1 \ldots \ldots \ldots \ldots \ldots \ldots \ldots$

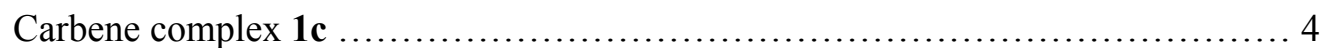

Carbene complex 1d ...................................................... 5

- General Method for Alkynylmonocarbenes Homocoupling ..................... 5

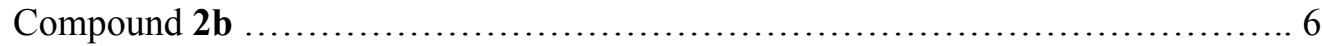

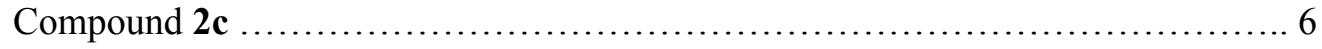

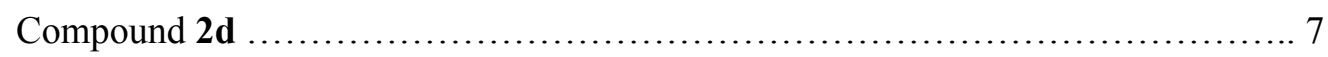

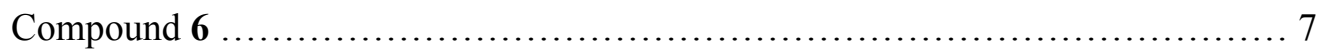

Compound 7 ............................................................... 7

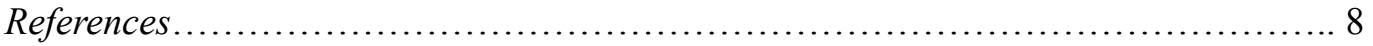




\section{Experimental Section}

\section{General Procedure.}

${ }^{1} \mathrm{H}$ NMR and ${ }^{13} \mathrm{C}$ NMR spectra were recorded at $22{ }^{\circ} \mathrm{C}$ on Bruker Avance 300 (300.1 and 75.4 MHz) or Bruker 200-AC (200.1 and $50 \mathrm{MHz})$ spectrometers. Chemical shifts are given in ppm relative to TMS $\left({ }^{1} \mathrm{H}, 0.0 \mathrm{ppm}\right)$ or $\mathrm{CDCl}_{3}\left({ }^{1} \mathrm{H}, 7.27\right) \mathrm{ppm}$ and $\mathrm{CDCl}_{3}\left({ }^{13} \mathrm{C}, 77.0 \mathrm{ppm}\right)$. IR spectra were taken on a Perkin-Elmer 781 spectrometer. THF was distilled from sodium/ benzophenone. Flame-dried glassware and standard Schlenk techniques were used for moisture sensitive reactions. Merck silica-gel (230-400 Mesh) was used as the stationary phase for purification of crude reaction mixtures by flash column chromatography. Identification of products was made by TLC (kiesegel 60F-254). UV light $(\lambda=254 \mathrm{~nm})$ and $5 \%$ phosphomolybdic acid solution in $95 \%$ EtOH were used to develop the plates.

All commercially available compounds were used without further purification.

Compounds 4,4'-Diethynyl-1,1'-biphenyl, ${ }^{1}$ alkynyl carbene complexes $\mathbf{1 a ^ { 2 }}, \mathbf{1 b}^{5 \mathrm{a}}, \mathbf{5}^{3}$ were synthesized following the methods previously reported.

\section{$p, p$ '-Bis-trimethylsilylethynyldiphenylether:}

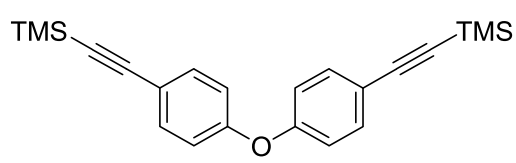

A solution of $2.0 \mathrm{~g}(6.1 \mathrm{mmol})$ of $p$-dibromodiphenylether, $0.44 \mathrm{~g}(0.63 \mathrm{mmol})$ of $\mathrm{PdCl}_{2}$ $\left(\mathrm{PPh}_{3}\right)_{2}, 0.33 \mathrm{~g}(1.25 \mathrm{mmol})$ of $\mathrm{PPh}_{3}, 0.12 \mathrm{~g}(0.63 \mathrm{mmol})$ of $\mathrm{CuI}$ and $1.5 \mathrm{~g}(15.25 \mathrm{mmol})$ of trimethylsilylacetilene in $45 \mathrm{~mL}$ of THF: $\mathrm{Et}_{3} \mathrm{~N}$ (5:2) was refluxed during $24 \mathrm{~h}$. The color of the solution changed from yellow to black. After 24 hours the mixture was allowed to reach room temperature and filtered on a short pad of Celite. The solvent was removed under reduced pressure and the residue was submitted to flash column chromatography $\left(\mathrm{SiO}_{2}, \mathrm{Hexane}\right)$ to give $1.46 \mathrm{~g}(66 \%)$ of the desired compound. ${ }^{1} \mathrm{H}-\mathrm{NMR}\left(\mathrm{CDCl}_{3}\right): \delta=7.48-7.42 \quad(\mathrm{~m}, 4 \mathrm{H}, \mathrm{ArH})$, 6.96-6.89 (m, 4H, ArH), 0.25 (s, 18H, TMS). ${ }^{13} \mathrm{C}-\mathrm{NMR}\left(\mathrm{CDCl}_{3}\right): \delta=156.9,133.7,118.8$,

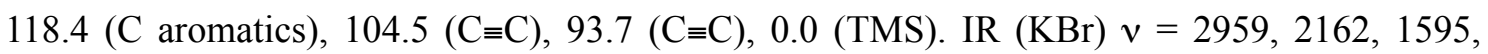
1497, 1242, 1217, 1165, 858, $833 \mathrm{~cm}^{-1}$. $\mathrm{C}_{23} \mathrm{H}_{29} \mathrm{OSi}_{2}$ Calcd: C 73.15, H 7.74, Found: C 73.39, H 7.52 . 


\section{$p, p$ 'Diethynyldiphenylether:}

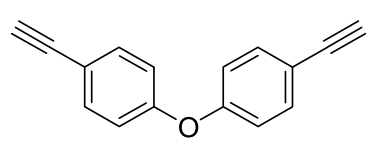

$\mathrm{K}_{2} \mathrm{CO}_{3}(2.76 \mathrm{~g}, 20.0 \mathrm{mmol})$ was added to a solution of $1.46 \mathrm{~g}(4.0 \mathrm{mmol})$ of $p$,p'-Bistrimethylsilylethynyldiphenylether in $38 \mathrm{~mL}$ of THF and $73 \mathrm{~mL}$ of $\mathrm{MeOH}$. The mixture was stirred at room temperature for $1 \mathrm{~h}$. under argon. $\mathrm{K}_{2} \mathrm{CO}_{3}$ was eliminated by filtration and the solvent under reduced pressure. After the crude was extracted with dichloromethane and the combined organic phases were washed with water and dried over $\mathrm{MgSO}_{4}$. After filtration the solvent was eliminated to give $878 \mathrm{mg}(100 \%)$ of a pale brown solid identified as the desired dialkynyl compound. ${ }^{1} \mathrm{H}-\mathrm{NMR}\left(\mathrm{CDCl}_{3}\right): \delta=7.48(\mathrm{~d}, J=8.7 \mathrm{~Hz}, 4 \mathrm{H}, \mathrm{ArH}), 6.96(\mathrm{~d}, J=8.7 \mathrm{~Hz}$, $4 \mathrm{H}, \mathrm{ArH}), 3.06(\mathrm{~s}, 2 \mathrm{H}, \mathrm{C} \equiv \mathrm{CH}) .{ }^{13} \mathrm{C}-\mathrm{NMR}\left(\mathrm{CDCl}_{3}\right): \delta=157.1,133.9,118.9,117.4$ (C aromatics), 83.1(C $\equiv \mathrm{C}), 77.7(\mathrm{C} \equiv \mathrm{C}) . \mathrm{IR}(\mathrm{KBr}): v=3317,3302,2110,1595,1495,1244,1165,835,785,762$ $\mathrm{cm}^{-1}$. $\mathrm{C}_{16} \mathrm{H}_{10} \mathrm{O}$ Calc: $\mathrm{C} 88.05, \mathrm{H} 4.62$, Found: C 88.39, H 4.54.

General Method for the synthesis of carbene complexes 1. To a solution of the corresponding diethynyl compound in dry $\mathrm{Et}_{2} \mathrm{O}$ at $-78{ }^{\circ} \mathrm{C}$ was added dropwise $n$-butyllithium $(1.6 \mathrm{M}$ in hexanes, 1:2.2 ratio). The mixture was stirred at $-78{ }^{\circ} \mathrm{C}$ for $45 \mathrm{~min}$ and then, chromium hexacarbonyl (1:2 ratio) was added at $0{ }^{\circ} \mathrm{C}$ in one portion. After stirring at this temperature for $15 \mathrm{~min}$, dry THF was also added to the mixture and then was let to stir at room temperature overnight. Afterwards, $\mathrm{Et}_{3} \mathrm{OBF}_{4}$ in excess (1:4 ratio) was added in one portion at $-78^{\circ} \mathrm{C}$. The solution was stirred at this temperature for $15 \mathrm{~min}$ and then allowed to reach room temperature for an additional hour. Solvents were removed under reduced pressure and the residue was dissolved in $\mathrm{Et}_{2} \mathrm{O}$ and filtered on a pad of silica gel. The solvent was evaporated and the residue was submitted to flash column chromatography ( $\mathrm{SiO}_{2}$, Hexane:Ethyl Acetate) to give a mixture of the corresponding monocarbene and bis-carbene complexes.

\section{Carbene complex 1c:}

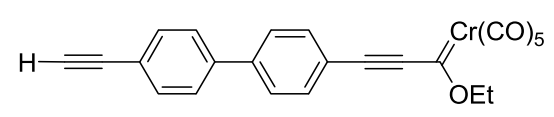

Following the general method from $300 \mathrm{mg}(1.48 \mathrm{mmol})$ of 4,4'-Diethynyl-1,1'biphenyl in $14 \mathrm{~mL}$ of dry $\mathrm{Et}_{2} \mathrm{O}, 2.1 \mathrm{~mL}$ of $n$-butyllithium (1.6 $\mathrm{M}$ in hexanes), $653 \mathrm{mg}(2.97$ $\mathrm{mmol})$ of $\mathrm{Cr}(\mathrm{CO})_{6}, 7.5 \mathrm{~mL}$ of $\mathrm{THF}$ and $1.13 \mathrm{~g}(5.93 \mathrm{mmol})$ of $\mathrm{Et}_{3} \mathrm{O}^{+} \mathrm{BF}_{4}^{-}$, were obtained 200 $\mathrm{mg}(35 \%)$ of monocarbene complex 1c and $90 \mathrm{mg}(14 \%)$ of the corresponding bis-carbene complex. 1c: ${ }^{1} \mathrm{H}$ NMR $\left(\mathrm{CDCl}_{3}\right): \delta=7.67$ (s, 4H, ArH), 7.60 (s, 4H, $\left.\mathrm{ArH}\right), 4.79$ (q, $J=7.1 \mathrm{~Hz}$, $\left.2 \mathrm{H}, \mathrm{OCH}_{2}\right), 3.19(\mathrm{~s}, 1 \mathrm{H}, \mathrm{C} \equiv \mathrm{CH}), 1.61\left(\mathrm{t}, J=7.1 \mathrm{~Hz}, 3 \mathrm{H}, \mathrm{CH}_{3}\right) .{ }^{13} \mathrm{C} \mathrm{NMR}\left(\mathrm{CDCl}_{3}\right): \delta=313.2$ 
(C=Cr), 225.7 (CO trans), 216.3 (CO cis), 143.3, 139.9, 133.2, 132.8, 127.4, 127.0, 122.2, 120.2 (C aromatics), $92.5(\mathrm{C} \equiv \mathrm{C}), 83.2(\mathrm{C} \equiv \mathrm{C}), 78.5(\mathrm{C} \equiv \mathrm{C}), 75.8\left(\mathrm{OCH}_{2}\right), 15.0\left(\mathrm{CH}_{3}\right)$. IR $(\mathrm{KBr})$ : $v=2152,2058,1942 \mathrm{~cm}^{-1} . \mathrm{C}_{26} \mathrm{H}_{14} \mathrm{CrO}_{6}$ : Calc: C 64.01, H 3.13, Found: C 63.87, H 3.35

\section{Carbene complex 1d:}

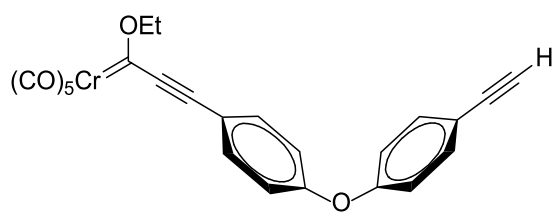

Following the general method, from $520 \mathrm{mg}(2.38 \mathrm{mmol})$ of $p, p^{\prime}-$

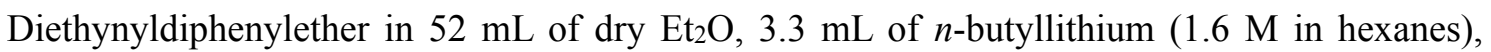
$1.05 \mathrm{~g}(4.76 \mathrm{mmol})$ of $\mathrm{Cr}(\mathrm{CO})_{6}, 26 \mathrm{~mL}$ of $\mathrm{THF}$ and $1.81 \mathrm{~g}(9.52 \mathrm{mmol})$ of $\mathrm{Et}_{3} \mathrm{O}^{+} \mathrm{BF}_{4}^{-}$, were obtained $218 \mathrm{mg}$ (20\%) of monocarbene complex 1d together with $241 \mathrm{mg}$ (14\%) of a brown solid identified as the corresponding bis-carbene. 1d. ${ }^{1} \mathrm{H}$ NMR: $\delta=7.59-7.52(\mathrm{~m}, 4 \mathrm{H}, \mathrm{ArH})$, 7.06- 7.01 (m, 4H, ArH), 4.75 (q, $\left.J=7.1 \mathrm{~Hz}, 2 \mathrm{H}, \mathrm{OCH}_{2}\right), 3.10$ (s, $\left.1 \mathrm{H}, \mathrm{C} \equiv \mathrm{CH}\right), 1.59$ (t, $J=7.1$ $\left.\mathrm{Hz}, 3 \mathrm{H}, \mathrm{CH}_{3}\right) .{ }^{13} \mathrm{C} \mathrm{NMR}\left(\mathrm{CDCl}_{3}\right): \delta=312.5(\mathrm{C}=\mathrm{Cr}), 225.6(\mathrm{CO}$ trans $), 216.4(\mathrm{CO}$ cis $), 160.1$, 155.8, 135.0, 134.0, 119.7, 118.6, 118.4, 115.5 (C aromatics), $92.3(\mathrm{C} \equiv \mathrm{C}), 82.7(\mathrm{C} \equiv \mathrm{C}), 77.3$ $(\mathrm{C} \equiv \mathrm{C}), 75.7\left(\mathrm{OCH}_{2}\right), 14.9\left(\mathrm{CH}_{3}\right)$. IR $(\mathrm{KBr}): v$ 3300, 2150, 2058, $1938 \mathrm{~cm}^{-1} . \mathrm{C}_{24} \mathrm{H}_{14} \mathrm{Cr} \mathrm{O}_{7}$ : Calc: C 61.81, H 3.03, Found: C 62.04, H 3.28.

\section{General Method for Alkynylmonocarbenes Homocoupling}

A slurry solution of distilled TMEDA was added to a solution of $\mathrm{CuCl}$ (I) in dry acetone. The mixture was stirred for one hour, whereupon it was repeatedly filtered until no more solid precipitate in the filtrate (in the most cases no more precipitated was obtained after the first filtration). After each filtration, the filter cake was washed with dry acetone. As representative, from $1.14 \mathrm{~g}(11.48 \mathrm{mmol})$ of $\mathrm{CuCl}(\mathrm{I}), 0.6 \mathrm{~mL}(3.71 \mathrm{mmol})$ of TMEDA and 56 $\mathrm{mL}$ of acetone were obtained $933 \mathrm{mg}$ of catalyst. To the resulting catalyst, a solution of the monocarbene in dry acetone was added dropwise. The mixture was stirred until monocarbene disappeared (checked by TLC). The reaction was quenched with water and filtered to eliminate the salts formed. The filtered solution was extracted with diethyl ether. The combined organic phases were washed with $\mathrm{HCl}(5 \%)$ and water, and finally dried over $\mathrm{MgSO}_{4}$. The desiccant was filtered off and the solvent was eliminated under vacuum. Purification by column chromatography on silica gel afforded the pure compounds. 


\section{Compound 2b:}

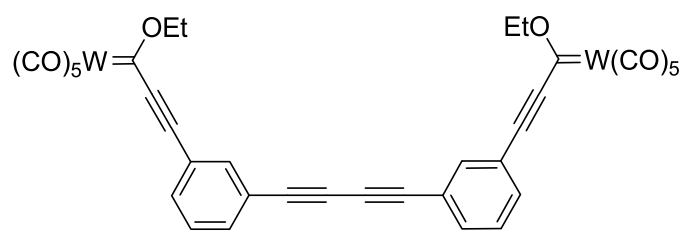

A solution of $100 \mathrm{mg}(0.2 \mathrm{mmol})$ of monocarbene $\mathbf{1 b}$ in $25 \mathrm{~mL}$ of dry acetone was added dropwise to a solution of $300 \mathrm{mg}$ of the catalyst obtained in $20 \mathrm{~mL}$ of acetone. The mixture was stirred for $1 \mathrm{~h}$ and quenched with $70 \mathrm{~mL}$ of water. After extraction and purification by column chromatography were obtained $56 \mathrm{mg}(55 \%)$ of a red-brown solid identified as the coupling compound $\mathbf{2 b} .{ }^{1} \mathrm{H}-\mathrm{NMR}\left(\mathrm{CDCl}_{3}\right) \delta=$ 7.63-7.42 (m, 8H, ArH), 4.70 (q, $\left.J=7.1 \mathrm{~Hz}, 4 \mathrm{H}, \mathrm{OCH}_{2}\right), 1.61\left(\mathrm{t}, J=7.1 \mathrm{~Hz}, 6 \mathrm{H}, \mathrm{CH}_{3}\right)$. ${ }^{13} \mathrm{C}-\mathrm{NMR}\left(\mathrm{CDCl}_{3}\right): \delta=285.9(\mathrm{C}=\mathrm{W}), 205.7$ (CO cis), 197.4, 197.3, 197.2 (CO trans), 136.0, 134.9, 133.3, 129.3, 122.8, 121.9 (C aromatics), $80.5(\mathrm{C} \equiv \mathrm{C}), 77.2\left(\mathrm{OCH}_{2}\right), 75.0$ $(\mathrm{C} \equiv \mathrm{C}), 14.8\left(\mathrm{CH}_{3}\right) . \mathrm{IR}\left(\mathrm{CHCl}_{3}\right): v=2068,1950,1215,758 \mathrm{~cm}^{-1} \cdot \mathrm{C}_{36} \mathrm{H}_{18} \mathrm{O}_{12} \mathrm{~W}_{2}:$ Calc: $\mathrm{C}$ 42.80, H 1.80, Found: C 42.64, H 1.62.

\section{Compound 2c:}

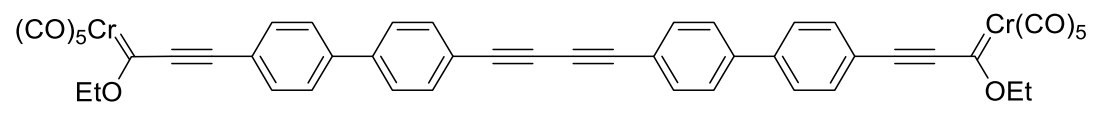

A solution of $146 \mathrm{mg}(0.32 \mathrm{mmol})$ of monocarbene $1 \mathrm{c}$ in $40 \mathrm{~mL}$ of dry acetone was added dropwise to a solution of $450 \mathrm{mg}$ of the catalyst in $30 \mathrm{~mL}$ of acetone. The mixture was stirred for $90 \mathrm{~min}$ and quenched with $100 \mathrm{~mL}$ of water. After extraction and purification by column chromatography were obtained $58 \mathrm{mg}(40 \%)$ of a purple solid identified as the coupling compound 2c. ${ }^{1} \mathrm{H}-\mathrm{NMR}\left(\mathrm{CDCl}_{3}\right): \delta=7.69-7.61(\mathrm{~m}, 16 \mathrm{H}$, $\mathrm{ArH}), 4.79$ (q, $\left.J=7.1 \mathrm{~Hz}, 4 \mathrm{H}, \mathrm{OCH}_{2}\right), 1.61\left(\mathrm{t}, J=7.1 \mathrm{~Hz}, 6 \mathrm{H}, \mathrm{CH}_{3}\right) .{ }^{13} \mathrm{C}-\mathrm{NMR}\left(\mathrm{CDCl}_{3}\right)$ : $\delta=313.1(\mathrm{C}=\mathrm{Cr}), 225.7$ (CO trans), 216.3 (CO cis), 143.0, 140.3, 133.3, 130.9, 128.8, 127.4, 127.2, 121.7, $120.3(\mathrm{C}$ aromatics and $\mathrm{C} \equiv \mathrm{C}), 92.6,81.9(\mathrm{C} \equiv \mathrm{C}), 75.8\left(\mathrm{OCH}_{2}\right), 75.3$ $(\mathrm{C} \equiv \mathrm{C}), 15.0\left(\mathrm{CH}_{3}\right) . \mathrm{IR}\left(\mathrm{CHCl}_{3}\right): v=3018,2060,1954,1215,762,669 \mathrm{~cm}^{-1} \cdot \mathrm{C}_{48} \mathrm{H}_{26}$ $\mathrm{Cr}_{2} \mathrm{O}_{12}$ : Calc: C 64.15, H, 2.92, Found: C 63.85, H, 2.74 . 


\section{Compound 2d:}

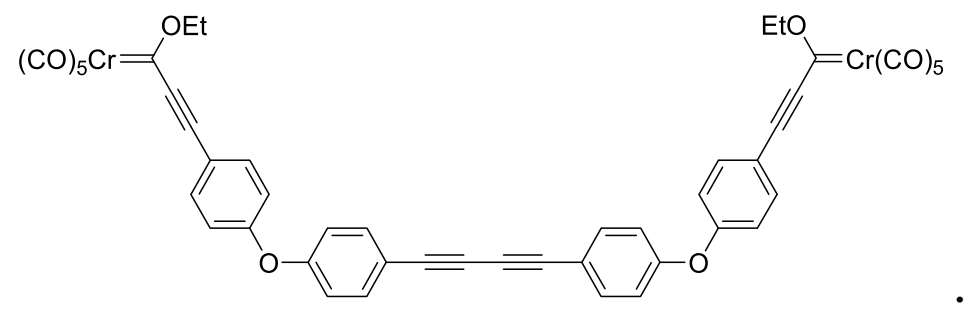

A solution of $119 \mathrm{mg}(0.24 \mathrm{mmol})$ of monocarbene $1 \mathbf{d}$ in $30 \mathrm{~mL}$ of dry acetone was added to a solution of $300 \mathrm{mg}$ of the catalyst in $20 \mathrm{~mL}$ of acetone. The mixture was stirred for $2 \mathrm{~h}$ and quenched with $80 \mathrm{~mL}$ of water. After extraction and purification by column chromatography were obtained $71 \mathrm{mg}(0.076 \mathrm{mmol}, 63 \%)$ of a purple solid identified as the coupling compound 2d. ${ }^{1} \mathrm{H}-\mathrm{NMR}\left(\mathrm{CDCl}_{3}\right): \delta=7.60-7.53(\mathrm{~m}, 4 \mathrm{H}$, ArH), 7.09-7.03 (m, 4H, ArH), 4.76 (c, $\left.J=7.1 \mathrm{~Hz}, 4 \mathrm{H}, \mathrm{OCH}_{2}\right), 1.59$ (t, $J=7.1 \mathrm{~Hz}, 6 \mathrm{H}$, $\left.\mathrm{CH}_{3}\right) .{ }^{13} \mathrm{C}-\mathrm{NMR}\left(\mathrm{CDCl}_{3}\right) \delta=312.6(\mathrm{C}=\mathrm{Cr}), 225.6$ (CO trans), 216.4 (CO cis), 159.8, 156.4, 135.0, 134.5, 119.7, 118.9, 117.8, 115.9 (C aromatics), 92.3, 80.9 (C $\equiv \mathrm{C}), 75.7$ $\left(\mathrm{OCH}_{2}\right), 73.9(\mathrm{C} \equiv \mathrm{C}), 15.0\left(\mathrm{CH}_{3}\right)$. IR $\left(\mathrm{CHCl}_{3}\right): v=3025,2060,1950,1495,1242 \mathrm{~cm}^{-1}$. $\mathrm{C}_{48} \mathrm{H}_{26} \mathrm{Cr}_{2} \mathrm{O}_{14}$ : Calc: C 61.94, H 2.82, Found: C, 61.67, H, 2.70.

\section{Compound 6:}

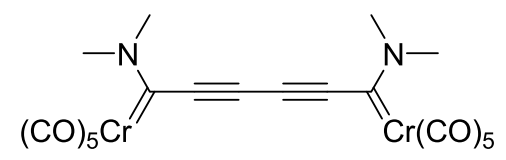

A solution of $200 \mathrm{mg}(0.7 \mathrm{mmol})$ of aminocarbene $\mathbf{5}^{3}$ in $30 \mathrm{~mL}$ of dry acetone was added to a solution of $600 \mathrm{mg}$ of the catalyst in $20 \mathrm{~mL}$ of acetone. The mixture was stirred for $5 \mathrm{~min}$. and quenched with $40 \mathrm{~mL}$ of water. After extraction and purification by column chromatography were obtained $60 \mathrm{mg}(30 \%)$ of a yellow solid identified as 6. ${ }^{4}$

\section{Compound 7:}

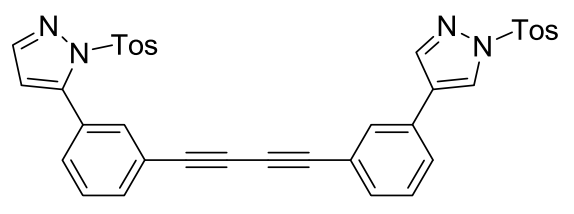


A solution of $60 \mathrm{mg}(0.08 \mathrm{mmol})$ of bis-carbene $2 \mathbf{a}$ and $30 \mathrm{mg}(0.16 \mathrm{mmol})$ of tosylhydrazine was stirred in $10 \mathrm{~mL}$ of THF for $5 \mathrm{~h}$. The solvent was removed in vacuo and the residue was solved in AcOEt and filtered through a pad of silica gel affording 38 mg (75\%) of 7. ${ }^{1} \mathrm{H}-\mathrm{NMR}\left(\mathrm{CDCl}_{3}\right): \delta=8.08-8.06(\mathrm{~d}, J=4 \mathrm{~Hz}, 2 \mathrm{H}, \mathrm{ArH}), 7.90-7.85(\mathrm{~m}$, $6 \mathrm{H}, \mathrm{ArH}), 7.77-7.72(\mathrm{~m}, 2 \mathrm{H}, \mathrm{ArH}), 7.47-7.42$ (m, 2H, ArH), 7.30-7.25 (m, 6H, ArH), $6.62(\mathrm{~d}, J=4 \mathrm{~Hz}, 2 \mathrm{H}, \mathrm{ArH}), 2.35\left(\mathrm{~s}, 6 \mathrm{H}, \mathrm{CH}_{3}\right) \cdot{ }^{13} \mathrm{C}-\mathrm{NMR}\left(\mathrm{CDCl}_{3}\right): \delta=155.6,145.9$, 134.1, 132.9, 132.6, 132.0, 130.4, 128.8, 127.2, 122.2, 106.3, (C aromatics), 81.3 $(\mathrm{C} \equiv \mathrm{C}), 74.2(\mathrm{C} \equiv \mathrm{C}), 21.7\left(\mathrm{CH}_{3}\right)$. IR $\left(\mathrm{CHCl}_{3}\right): v=1598,1530,1384,1217,1194 \mathrm{~cm}^{-1}$. $\mathrm{C}_{36} \mathrm{H}_{26} \mathrm{~N}_{4} 0_{4} \mathrm{~S}_{2}$ : Calc: C 67.27, H 4.08, Found: C, 67.43, H, 4.22.

\section{References}

1. Park, J. S. J. Am. Chem. Soc. 2006, 128, 7714.

2. (a) Fernández, I.; Sierra, M. A.; Mancheño, M. J.; Gómez-Gallego, M. y Ricart, S. Organometallics 2001, 20, 4304. (b) Fernández, I.; Mancheño, M. J.; Gómez-Gallego, M.; Sierra, M. A. Org. Lett., 2003, 5, 1237.

3. Rahm, A.; Wulff, W. D. ; Rheingold, A. L. Organometallics 1993, 12, 597.

4. (a) Hartbaum, C.; Mauz, E.; Roth, G.; Weissenbach, K.; Fischer, H. Organometallics 1999, 18, 2619. (b) Hartbaum, C.; Roth, G.; Fischer, H. Chem. Ber. 1997, 130, 479. (c) Hartbaum, C.; Fischer, H. Chem. Ber. 1997, 130, 1063. (d) Hartbaum, C.; Roth, G.; Fischer, H. Eur. J. Inorg. Chem. 1998, 191. (e) Hartbaum, C.; Fischer, H. J. Organomet. Chem. 1999, 578, 186. 